\title{
HUBUNGAN DAN KUALITAS PELAYANAN DENGAN LOYALITAS PELANGGAN PADA PT. HUTAMA TOUR DAN TRAVEL KOTA BENGKULU
}

\author{
Tito Irwanto 1); Ida Ayu Made Er Meytha Gayatri 2) \\ 1)Department of Management, Faculty of Economic, Universitas Dehasen Bengkulu \\ Email: ${ }^{1)}$ titoirwanto@unived.ac.id ${ }^{2)}$ cinta.gayatri@yahoo.com
}

\section{How to Cite :}

Irwanto, T. (2020). HUBUNGAN DAN KUALITAS PELAYANAN DENGAN LOYALITAS PELANGGAN PADA PT. HUTAMA TOUR DAN TRAVEL KOTA BENGKULU. EKOMBIS REVIEW: Jurnal IImiah Ekonomi Dan Bisnis, 3(1). DOI: https://doi.org/10.37676/ekombis.v8i2

\section{ARTICLE HISTORY}

Received [27 06 2020]

Revised [51 072020$]$

Accepted [2807 2020]

\section{KEYWORDS}

Promotion, Service

Quality, Customer Loyalty

This is an open access article under THE CC-BY-SA license

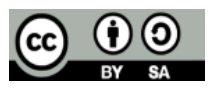

\begin{abstract}
ABSTRAK
Tujuan penelitian ini adalah untuk mengetahui hubungan kualitas pelayanan dengan loyalitas pelanggan pada PT. Hutama Tour dan Travel Kota Bengkulu. Sampel dalam penelitian ini sebanyak 32 orang pelanggan yang melakukan studi tour pada PT. Hutama Tour dan Travel Kota Bengkulu pada tahun 2019. Metode pengumpulan data yang di gunakan adalah kuesioner dan metode analisis yang digunakan adalah korelasi rank spearman dan pengujian hipotesis dengan uji t. Hasil korelasi rank spearman menunjukkan hubungan kualitas pelayanan dengan loyalitas pelanggan pada PT. Hutama Tour dan Travel Kota Bengkulu memiliki korelasi yang sangat kuat dengan nilai korelasi sebesar 0,864, ini berarti bahwa semakin baik kualitas pelayanan pada PT. Hutama Tour dan Travel Kota Bengkulu maka akan semakin tinggi pula loyalitas pelanggan pada PT. Hutama Tour dan Travel Kota Bengkulu. Hal ini diperkuat dengan hasil uji hipotesis bahwa thitung lebih besar dari ttabel $(9,389>1,697)$.
\end{abstract}

\section{ABSTRACT}

The aim of this study is to determine the relationship service quality with customer loyalty at PT. Hutama Tour and Travel of Bengkulu City. The samples in this study as many as 32 customers who conduct a study tour at PT. Hutama Tour and Travel of Bengkulu City in 2019. The data collection methods were used questionnaires and the analysis methods were used rank spearman correlation and hypothesis testing with $t$ test. The result of rank speannan correlation shows that relationship of service quality with customer loyalty at PT. Hutama Tour and Travel of Bengkulu City has a very strong correlation with a correlation value of 0.864 , this means that 
the better of service quality at PT. Hutama Tour and Travel of Bengkulu City then the increased of customer loyalty at PT Hutama Tour and Travel of Bengkulu City. This is reinforced by the hypothesis test result that tcoum is bigger than table $(9,389>1,697)$..

\section{PENDAHULUAN}

Loyalitas pelanggan memberikan dampak yang signifikan bagi profitabilitas perusahaan. Pelanggan yang loyal kemungkinan akan menunjukkan sikap dan perilaku positif, seperti pembelian ulang produk/jasa yang sama dan rekomendasi positif yang dapat mempengaruhi pelanggan yang telah ada (customer loyal) dan menarik konsumen (pelanggan potensial) menjadi pelanggan dari perusahaan bisnis itu. Pentingnya loyalitas pelanggan sebagai tujuan utama bagi banyak perusahaan, para akademisi dan profesional pemasaran telah berusaha untuk menemukan loyalitas pelanggan.

Kepuasan pelanggan dapat dikonseptualisasikan sebagai keseluruhan evaluasi pelanggan atas performance dari suatu penawaran. Jika hasil evaluasi terhadap suatu produk/jasa yang dipilih memenuhi atau melampaui ekspektasinya, maka pelanggan tersebut kemungkinan akan menunjukkan sikap positif, dan memiliki keinginan untuk membeli/menggunakan kembali produk/jasa yang sama (repurchase intentions), dan keinginannya untuk bertindak sebagai referensi bagi orang lain (advocacy intentions). Intinya bahwa kepuasan pelanggan akan memainkan peran penting dalam menjelaskan alasan pelanggan dipandang loyal.

Secara teoritis ketika pelayanan yang diberikan mampu memenuhi atau melampaui pengharapan atau ekspetasi pelanggan maka pelanggan tersebut merasa puas. Perusahaan perlu membangun sistem manajemen kualitas jasa untuk mengidentifikasi kesenjangan yang mungkin terjadi. Pentingnya meningkatkan kualitas pelayanan adalah untuk menciptakan kepuasan pelanggan dengan menjadikan pelanggan sebagai fokus utamanya. Kualitas pelayanan merupakan suatu bentuk penilaian konsumen terhadap tingkat layanan yang diterima (perceived services) dengan tingkat layanan yang diharapkan (expected service). Kualitas layanan difokuskan dalam pengukuran bentuk fisik (tangible), kehandalan (reliability), daya tanggap (responsiveness), jaminan (assurance), dan empati (empathy). Apabila kualitas pelayanan yang diberikan baik, maka konsumen akan memperoleh kepuasan atas produk/jasa dan cenderung melakukan pembelian ulang produk/jasa yang sama.

PT. Hutama Tour dan Travel Kota Bengkulu adalah travel agent yang melayani reservasi tiket pesawat dari berbagai maskapai seperti Lion Air, Sriwijaya Air, Garuda Indonesia dan Citylink Air. Travel ini dapat memberikan pelayanan pemesanan tiket lewat SMS (Short Message Service). Selain pemesanan tiket pesawat, PT. Hutama Tour dan Travel Kota Bengkulu juga melayani antar jemput penumpang di bandara dan juga melayani study tour dan perjalanan wisata. Berdasarkan fenomena yang terjadi pada PT. Hutama Tour dan Travel Kota Bengkulu terkadang tidak menanggapi pertanyaan konsumen mengenai ticketing jika sudah lewat jam 10 malam, maka dapat dilihat masih belum maksimalnya pelayanan yang diberikan oleh PT. Hutama Tour dan Travel Kota Bengkulu.

Berdasarkan latar belakang di atas, maka penulis tertarik untuk mengambil judul penelitian yaitu "Hubungan Kualitas Pelayanan dengan Loyalitas Pelanggan pada PT. Hutama Tour dan Travel Kota Bengkulu ". 


\section{Kualitas Layanan}

\section{LANDASAN TEORI}

Stemvelt (2009:210) menyatakan bahwa konsep kualitas layanan adalah suatu persepsi tentang revolusi kualitas secara menyeluruh yang terpikirkan dan menjadi suatu gagasan yang harus dirumuskan (formulasi) agar penerapannya (implementasi) dapat diuji kembali (evaluasi), untuk menjadi suatu proses yang dinamis, berlangsung, terus menerus dalam memenuhi kepuasan pelanggan. Apabila jasa yang diterima atau dirasakan sesuai dengan yang diharapkan, maka kualitas jasa dipersepsikan baik dan memuaskan

Menurut Tjiptono (2008:59), kualitas layanan adalah tingkat keunggulan yang diharapkan dan pengendalian atas tingkat keunggulan tersebut untuk memenuhi keinginan pelanggan. Dengan kata lain ada dua faktor utama mempengaruhi kualitas jasa, yaitu expected service dan perceived service atau kualitas jasa yang diharapkan dan kualitas jasa yang diterima atau dirasakan.

Sunyoto (2012:48), pada dasarnya sistem kualitas modern itu dibagi menjadi tiga yaitu kualitas desain, kualitas konfirmasi dan kualitas layanan.

1. Kualitas desain, pada dasarnya mengacu kepada aktivitas yang menjamin bahwa jasa baru atau jasa yang dimodifikasi, didesain sedemikian rupa untuk memenuhi keinginan dan harapan pelanggan serta secara ekonomis layak untuk dikerjakan. Dengan demikian, kualitas desain adalah kualitas yang direncanakan. Kualitas desain itu akan menentukan spesifikasi jasa dan merupakan dasar pembuatan keputusan yang berkaitan dengan pelayanan, spesifikasi penggunaan, serta pelayanan purna jual. Kualitas desain pada umumnya merupakan tanggungjawab pada Bagian Riset dan Pengembangan (R\&D), Rekayasa Proses (Process Engineering), Riset Pasar (Market Research) dan bagian-bagian lain yang berkaitan.

2. Kualitas konfirmasi mengacu kepada pembuatan jasa atau pemberian jasa layanan yang memenuhi spesifikasi yang telah ditentukan sebelumnya pada tahap desain itu. Dengan demikian kualitas konformansi menunjukkan tingkat sejauh mana jasa yang dibuat memenuhi atau sesuai dengan spesifikasi jasa. Pada umumnya, bagian-bagian jasa, perencanaan dan pengendalian jasa, pembelian dan pengiriman memiliki tanggungjawab utama untuk kualitas konformansi itu.

3. Kualitas pemasaran dan pelayanan purna jual berkaitan dengan tingkat sejauhmana dalam menggunakan jasa itu memenuhi ketentuan-ketentuan dasar tentang pemasaran, pemeliharaan dan pelayanan purna jual.

Kesenjangan pelayanan adalah hal yang penting, karena hal itulah yang merupakan penilaian konsumen secara keseluruhan terhadap apa yang diharapkan dibandingkan dengan apa yang diterima. Tujuan utama dalam meningkatkan kualitas pelayanan adalah memperkecil kesenjangan ini sedapat mungkin. Berikut adalah jenis-jenis kesenjangan yang dapat timbul dalam kualitas pelayanan (Lovelock, 2007: 96) :

1. Kesenjangan Pengetahuan

Perbedaan antara apa yang diyakini perusahaan akan diharapkan konsumen dan kebutuhan dan harapan konsumen yang sesungguhnya.

2. Kesenjangan Standar

Perbedaan antara persepsi manajemen terhadap harapan konsumen dan standar kualitas yang ditetapkan untuk penyerahan pelayanan.

3. Kesenjangan Penyerahan

138 | Tito Irwanto; Ida Ayu Made Er Meytha Gayatri; Hubungan Dan Kualitas Pelayanan

Dengan Loyalitas Pelanggan Pada Pt. Hutama Tour Dan Travel Kota Bengkulu 
Perbedaan antara standar penyerahan yang ditentukan dan kinerja perusahaan yang sesungguhnya.

4. Kesenjangan Komunikasi Internal

Perbedaan antara apa yang dianggap oleh iklan dan tenaga penjual perusahaan tersebut sebagai fitur produk, kinerja dan tingkat kualtas pelayanan dan apa yang benar-benar diinginkan oleh perusahaan.

5. Kesenjangan Persepsi

Perbedaan persepsi antara apa yang benar-benar diserahkan dan apa yang dianggap konsumen telah mereka terima (karena mereka tidak dapat menilai kualitas pelayanan secara akurat).

6. Kesenjangan Interpretasi

Perbedaan antara apa yang sesungguhnya dijanjikan perusahaan dalam upayaupaya komunikasinya dan apa yang konsumen pikir telah dijanjikan dalam komunikasi tersebut.

7. Kesenjangan Jasa

Perbedaan antara apa yang diharapkan konsumen akan mereka terima dan persepsi mereka terhadap pelayanan yang benar-benar diserahkan.

Menurut Lupiyoadi (2013:216) terdapat lima dimensi dari kualitas jasa yang terdiri dari:

1. Berwujud (tangible), yaitu kemampuan suatu perusahaan dalam menunjukkan eksistennya kepada pihak eksternal. Penampilan dan kemampuan sarana dan prasarana fisik perusahaan yang dapat diandalkan keadaan lingkungan dan sekitarnya merupakan bukti nyata dari pelayanan yang diberikan oleh pemberi jasa. Hal ini meliputi : fasilitas fisik (contoh : gedung, gudang, dan lain-lain), perlengkapan dan peralatan yang digunakan (teknologi) dan penampilan pegawainya.

2. Keandalan (Reliability), yaitu kemampuan perusahaan untuk memberikan pelayanan sesuai dengan yang dijanjikan secara akurat dan terpercaya. Kinerja harus sesuai dengan harapan pelangganyang berarti ketetapan waktu, pelayanan yang sama untuk semua pelanggan tanpa ada kesalahan dan sikap yang simpatik dan dengan akurasi yang tinggi.

3. Ketanggapan (responsivennes) yaitu suatu kebijakan untuk membantu dan memberikan pelayanan yang cepat ( responsive) dan tepat pada pelanggan, dengan penyampaian informasi yang jelas. Membiarkan pelanggan menunggu menciptakan persepsi yang negative dalam kualitas pelayanan.

4. Jaminan (assurances) yaitu pengetahuan, kesopansantunan, dan kemapuan para pegawai perusahaan dan untuk menumbuhkan rasa percaya para pelanggan kepada perusahaan. Hal ini meliputi beberapa komponen antara lain komunikasi ( communications), kredibilitas (credibility), keamanan (security), kompetensi (competence) dan sopan santun (courtesy).

5. Empati (empathy), yaitu memberikan perhatian yang tulus dan bersifat individual atau pribadi yang diberikan kepada para pelanggan dengan berupaya memahami keinginan mereka. Hal ini mengharapkan bahwa suatu perusahaan memiliki pengertian dan pengetahuan tentang pelanggan, memahami kebutuhan pelanggan secara spesifik, memiliki waktu pengoperasian yang nyaman bagi pelanggan.

Berdasarkan uraian di atas, dapat dipahami bahwa kualitas layanan dari keandalan dalam suatu organisasi dapat ditunjukkan keandalan pemberi pelayanan sesuai dengan bentuk-bentuk karakteristik yang dimiliki oleh pegawai tersebut, sesuai dengan keberadaan organisasi tersebut. Seorang pegawai dapat andal apabila 
tingkat pengetahuannya digunakan dengan baik dalam memberikan pelayanan, kemampuan keterampilan yang dimilikinya diterapkan sesuai dengan penguasaan bakat yang terampil, pengalaman kerja mendukung setiap pegawai untuk melaksanakan aktivitas kerjanya secara andal dan penggunaan teknologi menjadi syarat dari setiap pegawai yang andal untuk melakukan berbagai bentuk kreasi kerja untuk memecahkan berbagai permasalahan kerja yang dihadapinya.

\section{Loyalitas Pelanggan}

Kotler (2009 : 560), menerangkan bahwa konsumen yang loyal tidak diukur dari berapa banyak dia membeli, tapi dari berapa sering dia melakukan pembelian ulang, termasuk disini merekomendasikan orang lain untuk membeli. Loyalitas dapat dikelompokkan ke dalam dua kelompok yaitu loyalitas merek (brand loyalty) dan loyalitas toko (store loyalty) (Sutisna, 2009: 41).Misalnya seorang konsumen yang sudah sangat sering melakukan pembelian terhadap suatu satu merek produk, tidak ada lagi merek yang dipertimbangkan untuk dibeli selain merek produk dibelinya. Ketika merek produk itu tidak tersedia di toko yang ditujunya, dia terus berusaha mencari produk itu sampai ke tempat yang jauh sekalipun. Bahkan ketika merek barang itu tidak tersedia, dan petugas penjualan mengatakan merek produk yang dicarinya akan datang beberapa hari kemudian, dia bersedia menunggunya. Jika ada konsumen dalam pembeliannya berperilaku seperti itu, maka bisa disebut konsumen itu sangat loyal terhadap merek pilihannya (brand loyalty).Seperti halnya brand loyalty, store loyalty juga ditunjukkan oleh perilaku konsisten, tetapi dalam store loyalty perilaku konsistennya adalah dalam mengunjungi toko di mana konsumen bisa membeli merek produk yang diinginkan. Oleh karena itu, sejalan dengan apa yang diungkapkan oleh Assael, yaitu konsumen yang loyal terhadap merek akan juga loyal terhadap toko.

Hurriyati (2011 : 129) mengemukakan loyalitas konsumen (pelanggan) adalah komitmen konsumen bertahan secara mendalam untuk berlangganan kembali atau melakukan pembelian ulang produk/jasa terpilih secara konsisten dimasa yang akan datang, meskipun pengaruh situasi dan usaha-usaha pemasaran mempunyai potensi untuk menyebabkan perubahan perilaku.

Berdasarkan pengertian di atas, dapat dijelaskan bahwa loyalitas lebih mengacu pada wujud perilaku dari unit-unit pengambilan keputusan untuk melakukan pembelian secara terus menerus terhadap barang/jasa suatu perusahaan yang dipilih. Keuntungan-keuntungan yang akan diperoleh perushaan apabila memiliki konsumen yang loyal antara lain :

1. Dapat mengurangi biaya pemasaran (karena biaya untuk menarik konsumen yang baru lebih mahal).

2. Dapat mengurangi biaya transaksi.

3. Dapat mengurangi biaya turn over konsumen (karena penggantian konsumen yang lebih sedikit).

4. Dapat meningkatkan penjualan silang, yang akan memperbesar pangsa pasar perusahaan.

5. Mendorong word of mouth yang lebih positif, dengan asumsi bahwa pelanggan yang loyal juga berarti mereka yang merasa puas.

6. Dapat mengurangi biaya kegagalan (Seperti biaya penggantian).

Selanjutnya menurut Usmara (2008:122), loyalitas adalah komitmen yang mendalan untuk membeli kembali atau berlanggan kembali suatu produk atau jasa yang dipilih di masa mendatang, dengan cara membeli merek yang sama secara berulang-ulang, meskipun pengaruh situasional dan usaha-usaha pemasaran secara 
potensial menyebabkan tingkah laku untuk berpindah.Loyalitas pelanggan merupakan perilaku yang terkait dengan merek sebuah produk, termasuk kemungkinan memperbaharui kontrak merek di masa yang akan datang, berapa kemungkinan pelanggan mengubah dukungannya terhadap merek, berapa kemungkinan keinginan pelanggan untuk meningkatkan citra positif suatu produk. (Hasan, 2008:79).Jika produk tidak mampu memuaskan pelanggan, pelangga akan bereaksi dengan cara exit (pelanggan menyatakan berhenti membeli merek atau produk) dan voice (pelanggan menyatakan ketidak puasan secara langsung pada perusahaan. adalah :

Menurut Griffin dalam Mulyadi (2008:24), indikator dari loyalitas pelanggan

1. Melakukan pembelian secara teratur

Pelanggan yang telah melakukan hubungan transaksi dengan perusahaan dan merasa puas dengan apa yang di proleh akan membentuk hubungan yang erat antara pelanggan dengan apa yang ia inginkan, sehingga pelanggan tersebut akan melakukan pembelian secara teratur

2. Membeli antarlini produk produk dan jasa

Pelanggan bukan hanya membeli produk satu jenis sesudah yang lainnya, tetapi mereka membeli aksesoris untuk produk mereka, yang dimana mungkin pelanggan menambah item-item dari produk yang dibelinya.

3. Merekomendasikan produk kepada orang lain (refers other)

Pelanggan yang selalu merekomendasikan produk kepada orang lain adalah aset terbesar bagi perusahaan, dimna pelanggan ini selain merekomendasikan akan selalu membeli produk dan merek perusahaan, pelanggan akan menjadi juru bicara yang baik pada pelanggan lain dan pelanggan akan marah apabila ada orang lain menjelek-jelekkan merek perusahaan.

4. Menunjukkan kekebalan terhadap tarikan pesaing

Para pelanggan menolak untuk mengakui ada jenis-jenis produk lain, mereka yakin dengan produk yang mereka gunukan saat ini, dan sulit untuk beralih ke produk yang lain, mereka menggap produk yang digunakan saat ini adalah sudah benar-benar sesuai dan indah, dan banyak mereka sudah percaya dengan produk yang saat ini digunakan.

\section{METODE PENELITIAN}

\section{Metode Analisis}

1. Korelasi Rank Spearman

Dalam korelasi rank spearman, sumber data untuk kedua variabel yang akan dikonversikan dapat berasal dari sumber yang tidak sama, jenis data yang dikorelasikan adalah data ordinal, serta data dari kedua variabel tidak harus membentuk distribusi normal. Jadi korelasi rank spearman adalah bekerja dengan data ordinal atau berjenjang atau rangking, dan bebas distribusi ( Sugiyono, 2013:245), dengan rumus:

$$
\begin{aligned}
& \rho=1-\frac{6 \sum b i^{2}}{n\left(n^{2}-1\right)} \\
& \quad \text { (Sugiyono, 2013:245) } \\
& \text { Keterangan : } \\
& \rho \quad=\text { Koefisien Korelasi Spearman Rank }
\end{aligned}
$$


$\mathrm{n} \quad=$ Jumlah sampel

$\sum b i^{2}=$ Jumlah kuadrat dari selisih rank variabel $X$ dan variabel $Y$

Untuk menginterprestasikan angka yang dihasilkan dari perhitungan maka dapat digunakan pedoman sebagai berikut :

Tabel 1. Interprestasi Koefisien Korelasi

\begin{tabular}{|l|l|}
\hline Interval Koefesien & Tingkat Hubungan \\
\hline $0,00-0,199$ & Sangat rendah \\
\hline $0,20-0,399$ & Rendah \\
\hline $0,40-0,599$ & Sedang \\
\hline $0,60-0,799$ & Kuat \\
\hline $0,80-1,000$ & Sangat kuat \\
\hline
\end{tabular}

Sumber : Sugiyono, 2013:184

2. Uji Hipotesis

Uji Hipotesis untuk mengetahui tingkat signifikansi dari korelasi, maka penulis menggunakan statistik uji t dengan rumus sebagai berikut:

$$
t_{\text {hitwng }}=r \sqrt{\frac{n-2}{1-m^{2}}}
$$

( Sugiyono, $2013: 251$ )

$$
\begin{aligned}
& \text { Keterangan : } \\
& \mathrm{t}=\text { nilai uji } \mathrm{t} \\
& r=\text { nilai koefisien korelasi } \\
& \mathrm{n}=\text { jumlah sampel }
\end{aligned}
$$

Agar hasil perhitungan koefisien korelasi dapat diketahui signifikan atau tidak signifikan maka hasil perhitungan dari statistik uji t (t hitung) tersebut selanjutnya dibandingkan dengan ttabel. Tingkat signifikannya yaitu $5 \%(\alpha=0,05)$ dengan uji satu pihak dan derajat kebebasannya $(\mathrm{dk}=\mathrm{n}-2)$, artinya jika hipotesis nol ditolak dengan taraf kepercayaan $95 \%$, maka kemungkinan bahwa hasil dari penarikan kesimpulan mempunyai kebenaran $95 \%$ dan hal ini menunjukan adanya hubungan (korelasi) yang meyakinkan (signifikan) antara dua variabel tersebut.

Hipotesis yang digunakan dalam pengujian ini adalah :

H01: Diduga tidak ada hubungan yang signifikan antara kualitas pelayanan dengan loyalitas pelanggan pada PT. Hutama Tour dan Travel Kota Bengkulu .

Ha1: Diduga ada hubungan yang signifikan antara kualitas pelayanan dengan loyalitas pelanggan pada PT. Hutama Tour dan Travel Kota Bengkulu

Dengan kriteria pengujian sebagai berikut :

Apabila thitung < ttabel, maka HO diterima dan Ha ditolak.

Apabila thitung $>$ ttabel, maka $\mathrm{HO}$ ditolak dan Ha diterima.

\section{HASIL DAN PEMBAHASAN}

\section{Pembahasan}

142 | Tito Irwanto; Ida Ayu Made Er Meytha Gayatri; Hubungan Dan Kualitas Pelayanan

Dengan Loyalitas Pelanggan Pada Pt. Hutama Tour Dan Travel Kota Bengkulu 
1. Hubungan Kualitas Pelayanan dengan Loyalitas pelanggan Pada PT. Hutama Tour dan Travel Kota Bengkulu

Selanjutnya untuk menganalisa bagaimana hubungan kualitas pelayanan dengan loyalitas pelanggan pada PT. Hutama Tour dan Travel Kota Bengkulu menggunakan metode analisis korelasi rank spearman dengan rumus :

$$
\begin{aligned}
& \rho=1-\frac{6 \sum b i^{2}}{n\left(n^{2}-1\right)} \\
& \mathrm{n} \quad=\quad 32 \\
& \sum \text { bi2 }=\quad 740 \\
& \text { Maka perhitungan korelasi rank sperman sebagai berikut : } \\
& \rho=1-\frac{6(740)}{32\left(32^{2}-1\right)} \\
& \rho=1-\frac{4.440}{32(1.024-1)} \\
& \rho=1-\frac{4.440}{32(1.023)} \\
& \rho=1-\frac{4.440}{32.736} \\
& \rho=1-0,136 \\
& \rho=0,864
\end{aligned}
$$

Diketahui bahwa besar korelasi antara hubungan kualitas pelayanan dengan loyalitas pelanggan pada PT. Hutama Tour dan Travel Kota Bengkulu adalah sebesar 0,864. Artinya antara kualitas pelayanan dengan loyalitas pelanggan pada PT. Hutama Tour dan Travel Kota Bengkulu memiliki korelasi yang sangat kuat karena angka 0,864 terletak diantara angka 0,80 - 1,000. Ini berarti bahwa semakin bagus kualitas pelayanan pada PT. Hutama Tour dan Travel Kota Bengkulu maka akan semakin tinggi pula loyalitas pelanggan menggunakan jasa PT. Hutama Tour dan Travel Kota Bengkulu jika mengadakan study tour

2. Uji Hipotesis Untuk Hubungan Kualitas Pelayanan dengan Loyalitas pelanggan Pada PT. Hutama Tour dan Travel Kota Bengkulu

Rumus yang digunakan untuk menguji hipotesis statistik dalam penelitian tentang hubungan kualitas pelayanan dengan loyalitas pelanggan pada PT. Hutama Tour dan Travel Kota Bengkulu adalah uji t, berdasarkan hasil uji korelasi rank spearman maka dapat diketahui:

$$
\begin{aligned}
& \mathrm{t}=0,864 \\
& \mathrm{n}=32
\end{aligned}
$$

Rumus untuk uji thitung adalah sebagai berikut

$$
t=t \sqrt{\frac{n-2}{1-r^{2}}}
$$




$$
\begin{aligned}
t & =0,864 \sqrt{\frac{32-2}{1-0,864^{2}}} \\
t & =0,864 \sqrt{\frac{30}{1-0,746}} \\
t & =0,864 \sqrt{\frac{30}{0,254}} \\
t & =0,864 \sqrt{6118,110} \\
t & =0,864(10,868) \\
t & =9,389
\end{aligned}
$$

Dari Hasil Uji hipotesis diperoleh nilai thitung adalah 9,389 kemudian dibandingkan dengan nilai ttabel dengan level of signifikan ditetapkan 95\% dengan perhitungan satu arah dan $\mathrm{dk}=\mathrm{n}-2=32-2=30$, maka diketahui nilai ttabel sebesar 1,697 dengan kriteria :

H01 : kualitas pelayanan tidak mempunyai hubungan yang signifikan dengan loyalitas pelanggan pada PT. Hutama Tour dan Travel Kota Bengkulu

Ha1 : kualitas pelayanan mempunyai hubungan yang signifikan dengan loyalitas pelanggan pada PT. Hutama Tour dan Travel Kota Bengkulu .

Hasil uji hipotesis diketahui bahwa thitung lebih besar dari ttabel $(9,389$ $>1,697$ ). Dengan demikian hasil hipotesis adalah H02 ditolak dan Ha2 diterima. Artinya kualitas pelayanan mempunyai hubungan yang signifikan dengan loyalitas pelanggan pada PT. Hutama Tour dan Travel Kota Bengkulu. Hal ini menggambarkan bahwa pelanggan akan setia menggunakan jasa PT. Hutama Tour dan Travel Kota Bengkulu jika mengadakan study tour dikarenakan pelayanan yang diberikan sangat memuaskan.

Hasil penelitian korelasi rank spearman untuk hubungan kualitas pelayanan dengan loyalitas pelanggan pada PT. Hutama Tour dan Travel Kota Bengkulu memiliki korelasi yang sangat kuat dengan nilai korelasi sebesar 0,864 , ini berarti bahwa semakin baik kualitas pelayanan PT. Hutama Tour dan Travel Kota Bengkulu maka akan semakin tinggi pula loyalitas pelanggan pada PT. Hutama Tour dan Travel Kota Bengkulu. Hal ini diperkuat dengan hasil uji hipotesis bahwa thitung lebih besar dari ttabel $(9,389>1,697)$. Dengan demikian hasil hipotesis adalah $\mathrm{HO} 2$ ditolak dan $\mathrm{Ha} 2$ diterima. Artinya kualitas pelayanan mempunyai hubungan yang signifikan dengan loyalitas pelanggan pada PT. Hutama Tour dan Travel Kota Bengkulu .

Menurut Tjiptono (2008:59), kualitas layanan adalah tingkat keunggulan yang diharapkan dan pengendalian atas tingkat keunggulan tersebut untuk memenuhi keinginan pelanggan. Hal ini menggambarkan dengan adanya pelayanan maksimal yang diberikan oleh PT. Hutama Tour dan Travel Kota Bengkulu kepada para pelanggan, dan pelanggan merasa terpuaskan dengan pelayanan tersebut maka pelanggan akan selalu setia menggunakan jasa yang ada pada PT. Hutama Tour dan Travel Kota Bengkulu.

Pada PT. Hutama Tour dan Travel Kota Bengkulu selalu memberikan pelayanan yang mampu meningkatkan kepuasan kepada pelanggannya, jika pelanggan puas dengan pelayanan yang ada maka pelanggan akan melakukan 
pemesanan ulang bahkan memberitahukannya kepada orang lain. Pelanggan akan merekomendasikan PT. Hutama Tour dan Travel Kota Bengkulu kepada orang lain kerana pelayanan yang maksimal. Beberapa bentuk pelayanan yang diberikan oleh PT. Hutama Tour dan Travel Kota Bengkulu kepada pelanggan seperti pada saat cek in di bandara akan dilakukan oleh petugas dari PT. Hutama Tour dan Travel Kota Bengkulu, penyediaan bagasi pesawat yang langsung diurus oleh pihak PT. Hutama Tour dan Travel Kota Bengkulu, penginapan yang dipilih adalah hotel dengan fasilitas yang memadai, penyediaan kendaraan pada saat sampai di lokasi study tour dan pada saat makan PT. Hutama Tour dan Travel Kota Bengkulu akan memilih rumah makan sesuai dengan selera pelanggan.

\section{Kesimpulan}

\section{KESIMPULAN DAN SARAN}

Berdasarkan hasil penelitian berkenaan dengan hubungan promosi dan kualitas pelayanan dengan loyalitas pelanggan pada PT. Hutama Tour dan Travel Kota Bengkulu dapat disimpulkan Kualitas pelayanan memiliki hubungan yang sangat kuat dengan loyalitas pelanggan pada PT. Hutama Tour dan Travel Kota Bengkulu dengan nilai korelasi sebesar 0,864. Hal ini menggambarkan bahwa layanan yang ada pada PT. Hutama Tour dan Travel Kota Bengkulu seperti pada saat cek in di bandara akan dilakukan oleh petugas dari PT. Hutama Tour dan Travel Kota Bengkulu, penyediaan bagasi pesawat yang langsung diurus oleh pihak PT. Hutama Tour dan Travel Kota Bengkulu, penginapan yang dipilih adalah hotel dengan fasilitas yang memadai, penyediaan kendaraan pada saat sampai di lokasi study tour dan pada saat makan PT. Hutama Tour dan Travel Kota Bengkulu akan memilih rumah makan sesuai dengan selera pelanggan mampu membuat konsumen merasa puas.

\section{Saran}

Berdasarkan hasil penelitian yang dilakukan dapat dikemukakan saran Pelayanan yang ada sudah dinilai baik oleh pelanggan, untuk itu diharapkan dapat dipertahankan oleh PT. Hutama Tour dan Travel Kota Bengkulu dan kalau bisa lebih ditingkatkan lagi.

\section{DAFTAR PUSTAKA}

Assauri, Sofyan, 2007, Manajemen Pemasaran : Dasar, Konsep dan Strategi, Cetakan kedelapan, Penerbit ; PT. Raja Grafindo, Jakarta.

Dewi, Destati, 2014, Hubungan Bauran Pemasaran Dengan Loyalitas Konsumen memakai Kartu Indosat IM3 Di Bengkulu, Skripsi, Universitas Dehasen Bengkulu

Gitosudarmo,. Indriyo. 2008. Manajemen Pemasaran. edisi pertama. cetakan keempat. BPFE: Yogyakarta

Hasan. Ali. 2008. Marketing. Media Utama: Yogyakarta.

Hurriyati. Ratih. 2011. Bauran Pemasaran dan Loyalitas Konsumen. Alfabeta. Bandung

Kotler dan Amstrong, 2007, Prinsip-prinsip Marketing, Edisi Ketujuh, Penerbit Salemba Empat, Jakarta.

Kotler Philip \& Keller, Kevin Lane, 2009, Manajemen pemasaran, Edisi 13 Jilid 1. Prenhallindo, Jakarta.

Kotler. Philip. 2009. Manajemen Pemasaran. : Erlangga: Jakarta 
Lovelock Cristhoper H dan Lauren K. Wright. 2007. Manajemen Pemasaran Jasa. Alih bahasa Agus Widyantoro. Cetakan Kedua. Indeks: Jakarta

Lupiyoadi. Rambat. 2013. Manajemen Pemasaran Jasa Berbasis Kompetensi. Jakarta: Salemba Empat

Mitior. 2013. Hubungan Pelayanan dengan Kepuasan Pelanggan Pada Bengkel Candera Motor di Kaur Utara Kabupaten Kaur. Skripsi. Universitas Dehasen Bengkulu Mulyadi, Hari, 2008, Pengaruh Brand Personality terhadap Loyalitas Pelanggan Sampo Sunsilk (Survei pada Mahasisaawai FPIPS UPI Bandung Angkatan 2004-2006), Jounal Strategic, Volume 7 Nomor 13, Februari 2008

Rangkuti. Freddy. 2009. Measuring Customer Satisfation : Teknik Mengukur dan Strategi Meningkatkan Kepuasan Pelanggan. PT. Gramedia Pustaka Utama.Jakarta

Stemvelt, Robert C.. 2009. Perception of Service Quality. Alih Bahasa oleh Purwoko. Allyn and Bacon. Massachusetts.

Sugiyono. 2013. Metode penelitian pendidikan: pendekatn kuantitatif. kualitatif. dan $\mathrm{R} \& \mathrm{D}$. Alfabeta : Bandung

Sunyoto, Danang. 2012. Konsep Dasar Riset Pemasaran Dan Prilaku Konsumen. Cetakan Ke empat. Andi. Yogyakarta.

Sutisna. 2009. Perilaku Konsumen \& Komunikasi Pemasaran . Rosdakarya: Bandung

Swastha, Basu, 2006. Manajemen Pemasaran Modern;Yogyakarta: BPFE

Swastha, Basu , 2013. Manajemen Pemasaran;Tanggerang Selatan : Universitas Terbuka

Tjiptono. Fandy. 2008. Manajemen Pelayanan Jasa. Penerbit Andi. Yogyakarta Usmara. 2008. Strategi Baru Manajemen Pemasaran. Amoro Book: Yogyakarta

Yong. C.Z.. Yun. Y.W.. Loh. L.. 2007. The Quest for Global Quality. Alih Bahasa oleh Sutanto). Pustaka Delapratasa. Jakarta. 